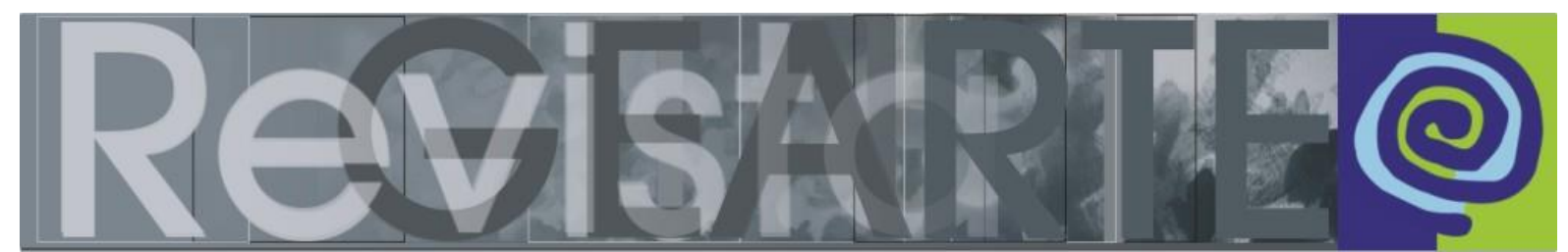

ISSN 2357-9854 | e-ISSN 2596-3198 (online)

\title{
Experiências estéticas/culturais na/para a formação de professores(as): pistas, recortes e rastros de um percurso investigativo no curso de Pedagogia da UFPE 1
}

\author{
Fabiana Souto Lima Vidal \\ (Universidade Federal de Pernambuco - UFPE, Recife/PE, Brasil)
}

RESUMO - Experiências estéticas/culturais na/para a formação de professores(as): pistas, recortes e rastros de um percurso investigativo no curso de Pedagogia da UFPE - O artigo contempla reflexões acerca das formações estéticas/culturais na formação em Pedagogia, a partir de pesquisa desenvolvida no PPGE/UFPE. Diálogo com autores(as) dos Estudos Culturais e da Arte/Educação contemporânea para pensar rupturas, culturas e estéticas e tomo a etnografia para conhecer, adentrar e transitar no campo de investigação. As interpretações foram elaboradas com orientações da Análise de Conteúdo. O estudo permitiu compreender que, ao expandir o repertório estético/cultural dos(as) estudantes, a formação docente provoca movimentos de encontros, comparações, confrontos com outras experiências vivenciadas e de expansão do repertório estético/cultural de cada estudante.

\section{PALAVRAS-CHAVE}

Experiências estéticas/culturais. Formação docente em Pedagogia. Estudos Culturais. Arte/Educação contemporânea. Etnografia.

ABSTRACT - Aesthetic/cultural experiences in/for teacher formation: tracks, snapshots and traces of an investigative path in the Pedagogy course at UFPE - The article contemplates reflections on aesthetic/cultural formations in Pedagogy, based on research developed at PPGE/UFPE. I dialogue with authors of Cultural Studies and Art/Contemporary Education to think about ruptures, cultures and aesthetics and I use ethnography to know, enter and transit in the field of investigation. The interpretations were elaborated according to Content Analysis guidelines. The study allowed me to understand that, by expanding the students' aesthetic/cultural repertoire, teacher formation provokes movements of encounters, comparisons, confrontations with other lived experiences and expansion of the aesthetic/cultural repertoire of each student.

\section{KEYWORDS}

Aesthetic/cultural experiences. Teacher formation in Pedagogy. Cultural Studies. Contemporary Art/Education. Ethnography.

RESUMEN - Experiencias estéticas/culturales en/para la formación de profesores(as): pistas, recortes y rastros de un recorrido investigativo en el curso de Pedagogía de la UFPE - El artículo contempla reflexiones acerca de las formaciones estéticas/culturales en la formación en Pedagogía, a partir de una investigación desarrollada en el PPGE/UFPE. Dialogo con autores(as) de los Estudios Culturales y del Arte/Educación contemporánea para pensar rupturas, culturas y estéticas y tomo la etnografía para conocer, entrar y transitar en el campo de investigación. Las interpretaciones fueron elaboradas con orientaciones del Análisis de contenido. El estudio permitió comprender que, al expandir el repertorio estético/cultural de los(as) estudiantes, la formación docente provoca movimientos de encuentros, comparaciones, enfrentamientos con otras experiencias vividas y de expansión del repertorio estético/cultural de cada estudiante.

\section{PALABRAS CLAVE}

Experiencias estéticas/culturales. Formación docente en Pedagogía. Estudios Culturales. Arte/Educación contemporánea. Etnografía. 


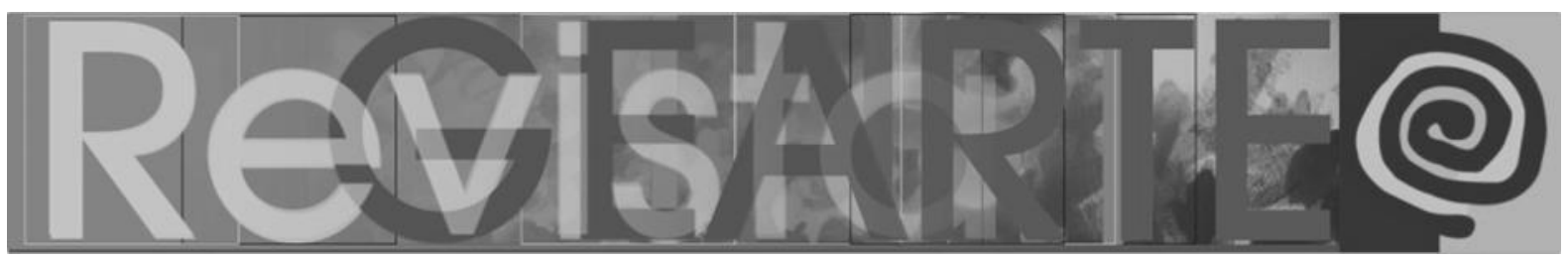

As reflexões reunidas no presente texto fazem parte da temática com a qual venho dialogando desde a pesquisa realizada no Doutorado em Educação, quando me debrucei sobre a problemática da formação estética/cultural. Nela, busquei compreender os percursos de formações estéticas/culturais na/para a formação de professores(as), no curso de Pedagogia da Universidade Federal de Pernambuco, Campus Recife, curso que, desde os anos de 1950, marca a formação de professores(as) no estado de Pernambuco.

Mobilizada por esse desejo de pesquisa e pelas provocações demandadas pela prática docente no campo das Artes Visuais, passei a buscar leituras e a estabelecer diálogos com os Estudos Culturais, levando-me a compreender melhor o campo no qual atuo e me movimento, bem como e os sujeitos com os quais venho aprendendo ao longo dos anos. Mas, não posso negar que essas leituras me impulsionaram a trilhar um caminho cheio de incertezas, a pisar em um lugar onde não me sentia segura, nem tão pouco confortável e, ainda hoje, me provocam e me inquietam. Dito isso, afirmo que os Estudos Culturais me serviram como lentes que possibilitaram realizar outras miradas e remexer os conceitos que eu carregava, muitos deles advindos da minha própria formação inicial. Esse não foi um processo fácil, em alguns momentos, precisei me desnudar e, aos poucos, deixar caírem as cascas que me encobriam, protegiam e imobilizavam, para, então, criar outra pele e fazer entender-me cada vez mais, modificando também meu modo de ver/ser/estar/agir no mundo e, ao mesmo tempo, rever as minhas práticas enquanto docente.

Nesse processo, o caleidoscópio passou a ser uma metáfora provocadora em todas as etapas da pesquisa; assim, com ela, venho tecendo escritas e conexões. Do francês kaléidoscope, segundo explica Souriau (1990, p. 932) em seu Vocabulaire d'Esthétique: "[...] o nome indica que o principal interesse deste instrumento óptico é de ordem estética", um objeto "[...] que faz ver belas imagens" (SOURIAU, 1990, p. 932), ou ainda, que nos possibilita um número infinito de composições aleatórias. Composto por espelhos e por pequenas peças - 


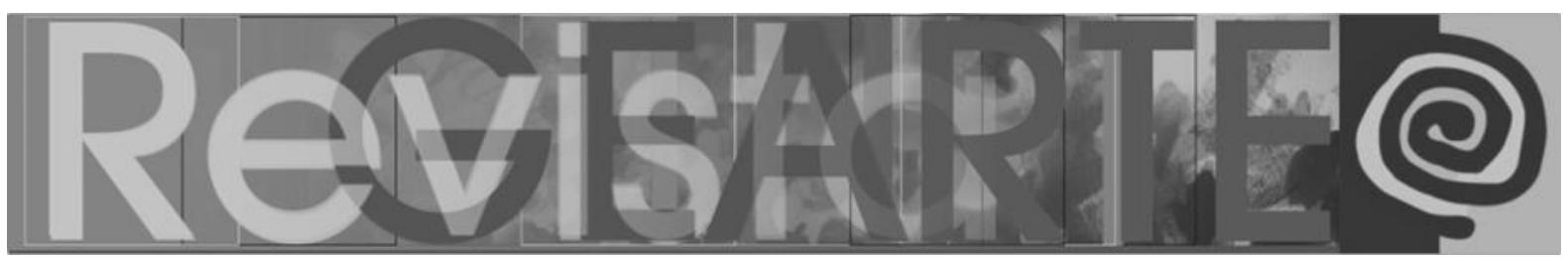

miçangas, contas, vidrilhos, brilhos, lantejoulas -, o caleidoscópio produz uma gama de imagens que não são previsíveis e que não podem ser antecipadas. Quanto mais peças figurarem na sua constituição, mais possibilidades de configurações a cada novo movimento, provocadas pela projeção das peças do seu interior nas paredes de espelhos, o que dá forma a uma gama de imagens, algumas mais complexas, cheias de detalhes, outras, mais simples e nítidas.

Aqui, em minha mesa de estudos, ao iniciar esta revisita e escrita dos recortes da viagem - ou aquilo que tentei fazer depois de ter estado lá, imersa no campo - sou tomada mais uma vez pela sensação de desassossego que mobilizou todo o movimento de pesquisa; talvez, por saber que muitos giros foram dados no caleidoscópio e que o contexto pesquisado, também não é mais o mesmo. Em certa medida, Geertz (2012, p. 7, grifo do autor) me conforta dessas inquietações, levando-me a refletir um pouco mais quando diz que "[...] tentar encontrar o desenho certo na tapeçaria de seus próprios escritos pode ser tão desanimador como tentar encontrá-lo na própria vida; tentar tecê-lo post facto [...] é uma verdadeira tentação".

Nessa revisita utilizo como aporte o poeta Saramago quando, em seu livro Viagem a Portugal, me provoca a pensar a importância de olhar mais de uma vez para o mesmo lugar, de olhar profundamente, atentamente, para descobrir-se transformado(a), tomando os mapas já traçados e os caminhos já percorridos para, com eles, (re)visitar e (re)inventar o nosso próprio olhar e os nossos percursos, em um constante ir e vir, na intenção de unir mais elementos a partir de outras lentes e recortes:

É preciso ver o que não foi visto, ver outra vez o que se viu já, ver na primavera o que se vira no verão, ver de dia o que se viu de noite, com o sol onde primeiramente a chuva caía, ver a seara verde, o fruto maduro, a pedra que mudou de lugar, a sombra que aqui não estava. É preciso voltar aos passos que foram dados, para repetir e para traçar caminhos novos ao lado deles. É preciso recomeçar a viagem. Sempre. (SARAMAGO, 2007, p. 476) 


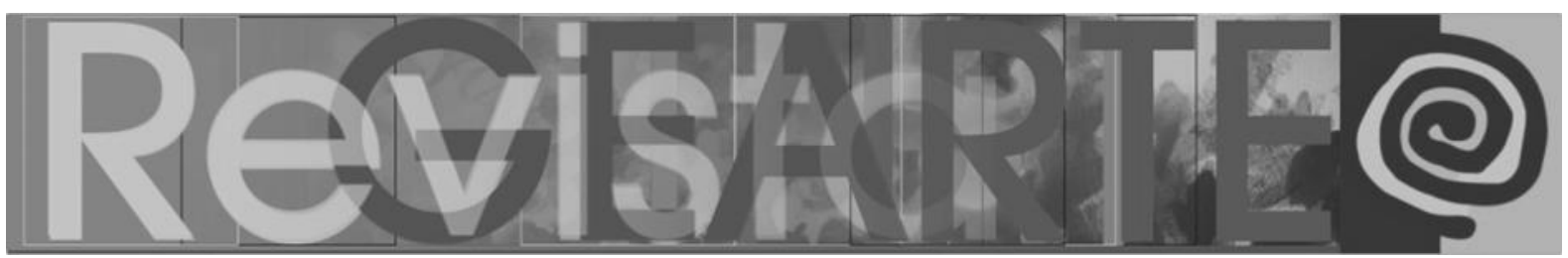

Desse modo, afirmo que, enquanto parte do desdobramento da pesquisa realizada, este texto foi construído a partir das memórias, das experiências, dos atravessamentos vividos no campo de investigação e, aqui, retomo àquilo que ainda reverbera e me deixa reflexiva, dando corpo a esta escrita.

\section{Juntando peças no caleidoscópio: demarcando pontos do debate teórico}

Na construção do debate teórico, arrisquei, inspirando-me em Kerlan (2004, p. 151), a "[...] vizinhança eclética de perspectivas teóricas”. Dito de outra maneira, busquei fazer também o que propõe Dewey (2010a), quando reconhece que cada perspectiva, velha ou nova, tem contribuições a nos trazer. Sendo assim, insisti em tirar referenciais das caixas e gavetas, tentando estabelecer diálogos entre conteúdos e autores(as), a fim de propiciar que se misturassem, transbordassem.

Dentre as peças utilizadas para compor o caleidoscópio, destaco o debate mais intenso com os Estudos Culturais e o campo da arte/educação, por entender que a visão expandida destes campos rompe com as hierarquias estabelecidas, visibiliza as margens, os sujeitos e as fronteiras geralmente excluídos, possibilitando ampliar as reflexões acerca das formações estéticas/culturais de professores(as). Assim, visando alargar as imagens produzidas e permitir escapar da armadilha de formar representações ou ideias prévias, herméticas, busco ressaltar os debates sobre culturas e estéticas fomentados por esses campos de conhecimentos, por entender que estes elementos trazem as nuances que dão corpo a um pensar contemporâneo na/para a formação de professores(as).

Encontro, na ideia de teia de significados trazida por Geertz (2012), alicerce para pensar culturas, no plural, por entender que essa visão ampliada agrega e possibilita a formação de diferentes tramas, redes, cruzamentos, diluição de fronteiras, imagens que ilustram múltiplas vozes, posicionamentos e deslocamentos.

Ainda sobre culturas, Darras (1995) acrescenta elementos quando diz: 


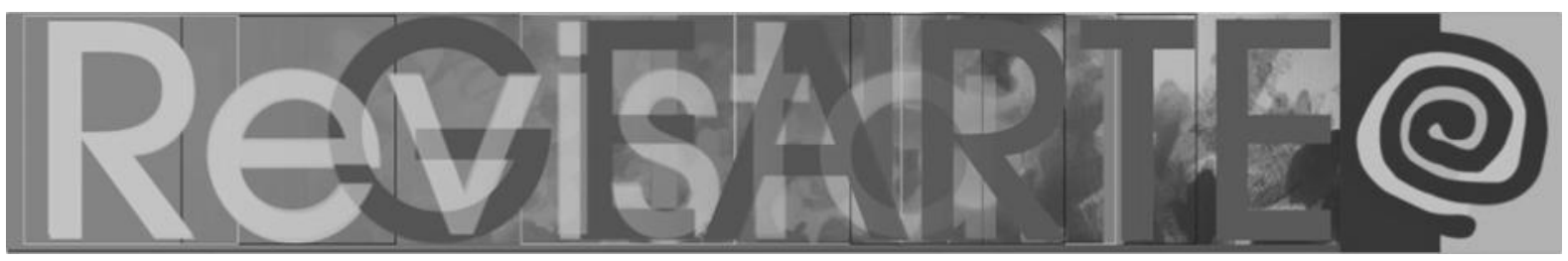

Hoje mais do que nunca, surge dessa abordagem de mobilidade, de influência e de transversalidade. $O$ desenvolvimento das redes globais, a desmaterialização das obras, a mobilidade dos povos e de suas culturas enfraquecem todas as fronteiras. (DARRAS, 1995, p. 47)

Costa, Silveira e Sommer (2003), pesquisadores(as) dos Estudos Culturais, unem outros aspectos ao debate, através da denúncia e da desconstrução das polaridades ainda existentes quando se trata de culturas - alta cultura/cultura de massa, cultura burguesa/cultura operária, cultura erudita/cultura popular, ou ainda, cultura de centro/cultura das margens. Esses binarismos revelam modos de pensar/agir que separam e classificam as culturas em centro e periferia, sendo comumente entendidas como as de centro àquelas nomenclaturas que ainda hoje são tomadas como referência, como a máxima expressão e a tudo o que se relaciona à ideia de beleza, harmonia, estética e Arte com A maiúsculo, ou ainda, aquele tipo de produção artística chamada de grande Arte. Por outro lado, na periferia estariam as manifestações das demais culturas, consideradas inferiores, e tudo o que se relaciona à pobreza estética ou a uma arte tida como menor e de pouca relevância.

Por sua vez, Barbosa (2008) também amplia as questões acerca do significado de culturas e apresenta dois conceitos que têm norteado grande parte das discussões contemporâneas no campo da Arte/Educação: cultura a partir de um significado restrito e cultura a partir de um significado amplo. No modo restrito, cultura está ligada àquilo que caracteriza um sujeito dotado(a) de informações e conhecimentos que, convencionalmente, o classificam como pertencente ou conhecedor(a) da alta cultura. Já no modo amplo, cultura é toda e qualquer produção do ser humano, conforme explicita: "Para ser mais específica, diria que cultura é um campo organizado de atividade humana coletiva que tem características específicas que operam dentro de limites mais ou menos definidos, os quais estão em constante modificação" (BARBOSA, 2008, p. 1).

Além da compreensão de culturas, também se faz necessário ampliar o olhar para a noção horizontal de estéticas, no plural, de forma não hierarquizada. 


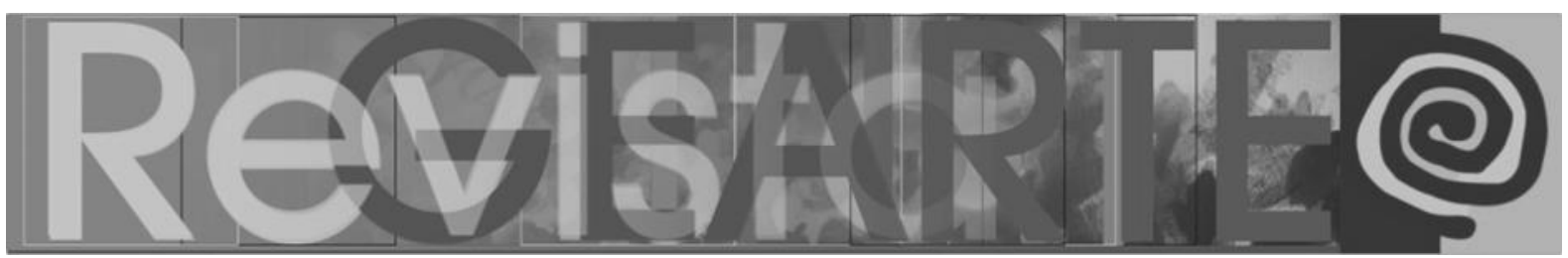

Essa noção dilui fronteiras e expande as possibilidades de pensar formações estéticas/culturais em diálogo estreito com o pensamento contemporâneo do campo da arte/educação e com os Estudos Culturais, os quais defendem que a estética vai além dos critérios fechados e tradicionais de beleza e da relação estreita com o campo da arte, conforme afirma Genin (2007, p. 7): "[...] ela não se reduz ao estudo de obras de arte nem a análise de normas e critérios de beleza", alinha-se, deste modo, à perspectiva expandida de culturas.

As reflexões supracitadas trazem rebatimentos para pensar a relação entre educação e culturas na contemporaneidade. Assim, elas podem ser pensadas a partir de uma ideia de formação ampliada, enquanto rede complexa, em um tempo marcado por inúmeras caracterizações e mudanças.

Diante do exposto, parto da compreensão de que a dimensão estética está no mundo, na sociedade, nos diversos grupos, nas culturas, no cotidiano das gentes, logo, não é extrínseco ao processo educacional e, tampouco, pode ser silenciado nele. Isso implica afirmar que a ideia de estética horizontal, no campo educacional, aponta para um olhar mais abrangente na/da formação nos mais diferentes níveis e insere-se em uma necessidade ampla na contemporaneidade, sobretudo, na formação de futuros(as) trabalhadores(as) culturais. Alinhando-se com esse pensar, Giroux (1999, p. 191) diz que "[...] é fundamental para reconstrução dos estudos culturais a necessidade de se desenvolver um discurso que acentue as conexões orgânicas entre os trabalhadores culturais e a vida cotidiana", uma vez que estes(as) profissionais estão diretamente ligados(as) à formação de subjetividades dos sujeitos, produzindo conhecimento e construindo identidades.

Ao discutir Estética e Educação, Perissé (2009) corrobora os aspectos citados e acrescenta:

\footnotetext{
Um professor esteticamente mais bem formado cultivará (eis um pressuposto somado à esperança) um comportamento especial no cotidiano escolar, porque olhará de modo especial os seus alunos, verá neles artistas em potencial, respeitando essa possibilidade, acreditando nela como realidade alcançável. (PERISSÉ, 2009, p. 54)
} 


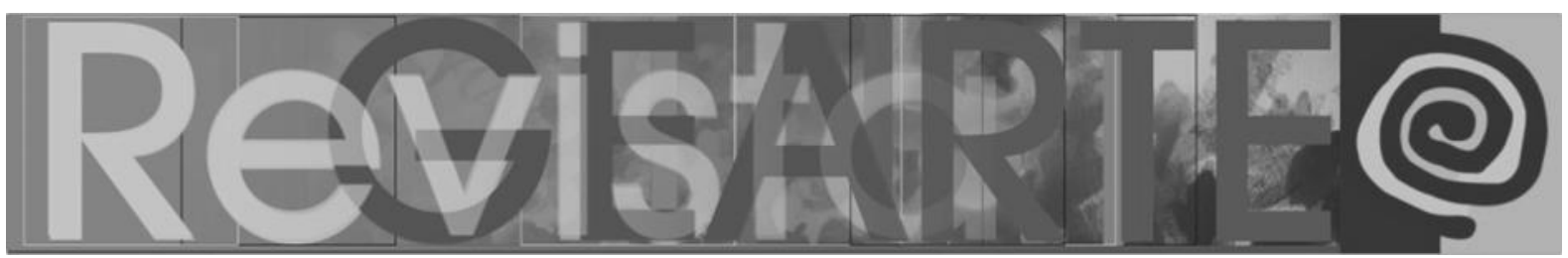

O fragmento acima impulsiona a olhar de forma inquieta para a presença ainda tímida desse pensar na/para a formação de professores(as). Também, impulsiona a enxergar os possíveis rebatimentos nas práticas docentes em todos os níveis da educação, levando ao encontro da crítica à problemática tecida por Lauand (2009) quando diz:

É que nós, professores, carecemos de experiências estéticas significativas, pois nossa formação para a beleza, para a arte, para a criação é deficiente. Daí, em consequência, seja deficiente, nesse aspecto, nossa prática educativa. (LAUAND, 2009, p. 7)

Na busca por modos de pensar a formação de professores(as) a partir de outras bases, Larrosa e Kohan (2014, p. 6) dão corpo às ideias quando destacam a necessidade de fissurar o que já está instalado e buscar caminhos para que "[...] nos livremos das verdades pelas quais educamos, nas quais nos educamos". Isso implica dizer que, no campo formativo, concebe-se vivenciar experiências estéticas/culturais na/para a formação de professores(as) como forma de "[...] ampliar nossa liberdade de pensar a educação e de nos pensarmos a nós próprios, como educadores" (LARROSA; KOHAN, 2014, p. 6).

Essas contribuições são provocadoras e deixam pistas para (re)pensar o fato de que existem mudanças nas práticas e na própria forma de se reconhecer professor(a), enquanto sujeito de um processo de formação de si e do outro. Isto é, a forma de se reconhecer professor(a) é afetada quando formações estéticas/culturais passam a ser validadas na formação de professores(as), quando começamos a percebê-las conectadas com nossa vida, quando nos deixamos atravessar e fazemos com que elas transbordem em nossas práticas e no nosso modo de ver/ser/estar/agir no mundo.

A partir dos elementos expostos, defendo que a presença de experiências estéticas/culturais na formação inicial de professores(as) traz aporte para uma formação mais ampla, capaz de abastecer os(as) futuros(as) docentes com elementos necessários para pensar um currículo enquanto terreno das 


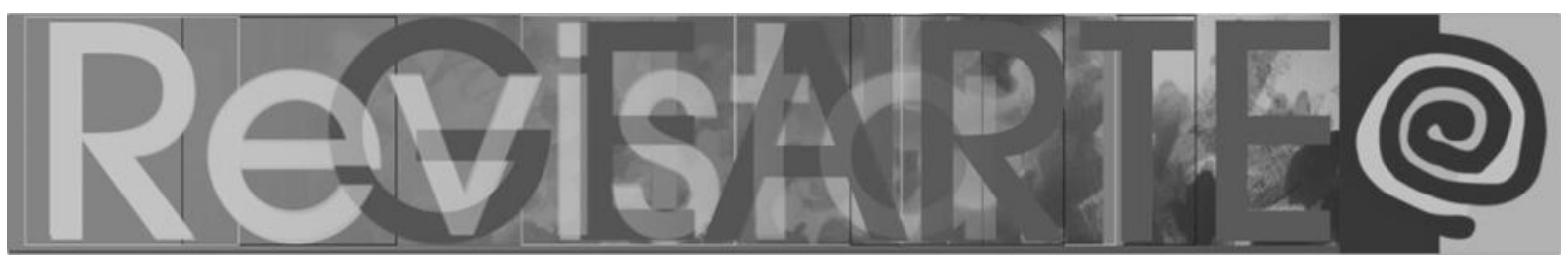

possibilidades - propício na/para a construção de outros modos de ser professor(a). Isso implica (re)construir outra lógica na/para a formação docente, para além da necessidade centrada nas buscas por modelos metodológicos e por estudos em determinados campos de conhecimentos que dão notoriedade e status à formação e/ou aos mecanismos de avaliação que comumente atendem aos interesses e propostas encampadas por tantas políticas e matrizes curriculares. Numa perspectiva oposta ao pensamento enraizado, as formações estéticas/culturais fissuram, arejam e provocam a formação de professores(as) a sair dos modelos herméticos com os quais historicamente vêm se construindo.

\section{Das escolhas teórico-metodológicas e de análise: pistas dos caminhos percorridos}

Delinear um percurso metodológico de uma pesquisa no campo dos Estudos Culturais exige abertura para possibilidades de diálogos e itinerários de investigação, tendo em mente o "tumulto teórico" (COSTA, SILVEIRA, SOMMER, 2003 , p. 39) que, tantas vezes, pode ser usado para nomear este campo. Isso implica afirmar que o processo metodológico pode ser visto também caleidoscopicamente, a partir da confluência de caminhos, nem sempre seguros, iluminados, firmes, ora guiados pelo objeto ora pelas escolhas do(a) pesquisador(a).

Nelson, Treichler e Grassberg (2012, p. 9) também reforçam a pluralidade de opções que podem orientar as escolhas metodológicas das pesquisas que buscam ancoragem nos Estudos Culturais, por ser este um campo aberto às experimentações, às colagens e bricolagens. Desse modo, afirmam que "[...] nenhuma metodologia pode ser privilegiada ou mesmo temporariamente empregada com total segurança e confiança, embora nenhuma possa tampouco ser eliminada antecipadamente" (NELSON; TREICHLER; GRASSBERG, 2012, p. 9).

Encontrei no suporte teórico-metodológico da etnografia numa perspectiva contemporânea, abertura para desbravar as ideias e desejos, adentrar no campo, vivenciá-lo e compreendê-lo de maneira mais aprofundada, permitindo uma 


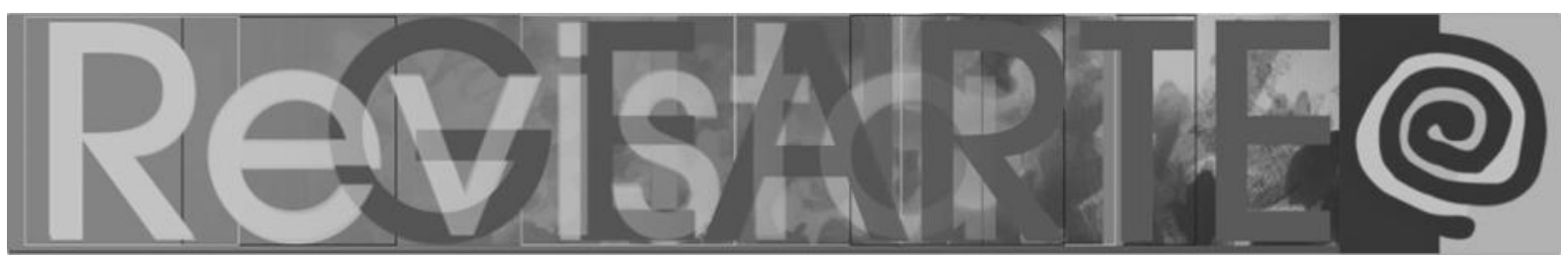

aproximação maior e mais intensa com os sujeitos que dele participam. Essa perspectiva vem se constituindo referencial para pesquisas no campo dos Estudos Culturais, pelo acolhimento dado à experiência direta e intensa no campo investigativo, a autorreflexividade, a simbiose entre os sujeitos provocada pela imersão do(a) pesquisador(a) no campo, além da visão descritiva e por buscar entender as culturas considerando as subjetividades, o que corroborou a escolha deste caminho como inspirador do percurso investigativo (KLEIN; DAMICO, 2012; MEYER; PARAÍSO, 2012; SANTOS, 2005; FINO, 2008).

Ao tomar esses elementos como orientadores, adotei a perspectiva do viajante para delinear o percurso metodológico. Não do viajante turista que se contenta com roteiros prontos e que estabelece uma relação superficial com o lugar, ao contrário, busquei a perspectiva do viajante que planeja, sonha e pesquisa a sua própria viagem, que deseja viver o lugar, conhecer, adentrar e frequentar, não apenas os lugares comumente visitados. Busquei os lugares incomuns, aqueles que os(as) habitantes locais transitam e convivem, o que me permitiu divagar em planos, projetos e possibilidades. Ao mesmo tempo, essa perspectiva permitiu, em alguns momentos, no decorrer da viagem, procurar pelos roteiros menos previsíveis, abriu espaço para andar por caminhos até então desconhecidos, muitas vezes, guiada apenas pelo desejo, sem bússolas, mapas ou aparelhos e sistemas de localização, levando-me a reconhecer que um pouco da imprevisibilidade nos caminhos pode ser encarada como uma abertura para descobertas e deleites. Afinal, numa viagem, "se perder" pode propiciar encantamentos, encontros e experiências inusitadas.

De início, passei a entender que para observar formações estéticas/culturais de professores(as) era preciso também flanar. De acordo com o Dicionário Priberam, flanar, palavra de origem francesa, flâneur, significa "Passear sem destino e sem pressa, por mera distração" (PRIBERAM, 2014), permitir-se sair do cotidiano, quebrar a rotina e buscar diferentes modos de abastecer-se esteticamente, ou seja - utilizando-me de uma palavra comum no vocabulário 


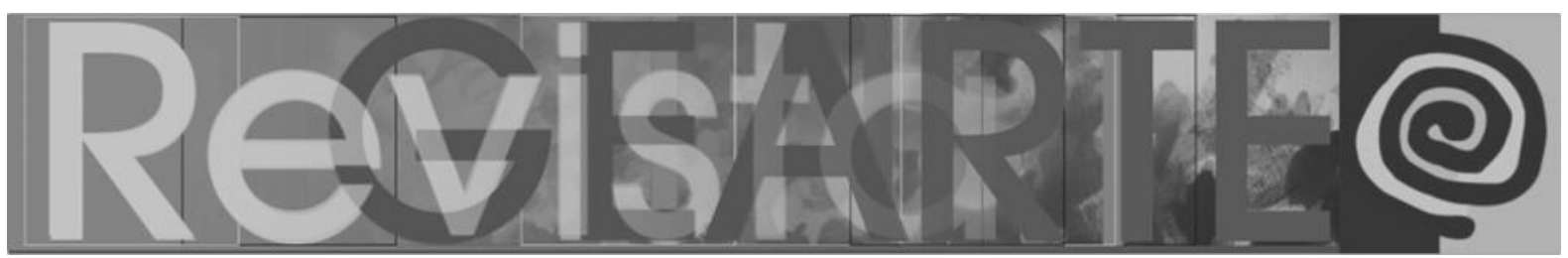

nordestino -, perambular, no caso, pelo curso de Pedagogia da UFPE. Assim, ao longo da imersão no campo de pesquisa, a ideia do flâneur foi mobilizadora para orientar as possibilidades de ver melhor o lugar, para andar pelos seus corredores e frequentar diferentes espaços físicos, desde os eventos que aconteceram nos espaços abertos e aulas de campo, até o olhar atento para o interior das salas, tentando estar lá com esse olhar também caleidoscópico.

Ainda que o lugar da viagem já estivesse determinado, o curso de Pedagogia da UFPE, e que alguma noção e leituras que me davam aporte e tranquilidade acerca do mesmo, já haviam sido realizadas, fez-se necessário preparar a bagagem. Nesse momento, encontrei em Manoel de Barros abertura para os imprevistos e as rotas não traçadas: "Pois é nos desvios que encontra as melhores surpresas e os ariticuns maduros" (BARROS, 2013, p. 295).

Partindo das contribuições apresentadas, destaco que, para além da ideia de flâneur, utilizei a observação participante, realizada o ano letivo de 2014, em sete componentes curriculares de diferentes períodos do curso, obrigatórias e eletivas, distribuídas nos três turnos, nas quais foram produzidos registros em fotografias e em sete diários de campo, contendo as percepções, situações, ideias, diálogos, comentários, inquietações, reflexões extraídas e percebidas nas diferentes experiências de observações vividas, a partir do olhar mais atento para os gestos dos(as) professores(as) e dos(as) estudantes, a escuta cuidadosa dos sujeitos, além das anotações realizadas em diferentes momentos dentro e fora das salas de aula. Assim, tudo o que saltava aos olhos e aguçava os ouvidos durante as observações foi cuidadosamente registrado e compôs os materiais que serviram de orientadores das análises realizadas posteriormente. Mais especificamente, para o presente artigo, relato alguns recortes de experiências estético/culturais vivenciadas nas observações realizadas em três componentes curriculares ${ }^{3}$.

Ainda, considero pertinente destacar que, para a entrada no campo, não foram elencadas categorias prévias e herméticas para orientar os olhares ou a 


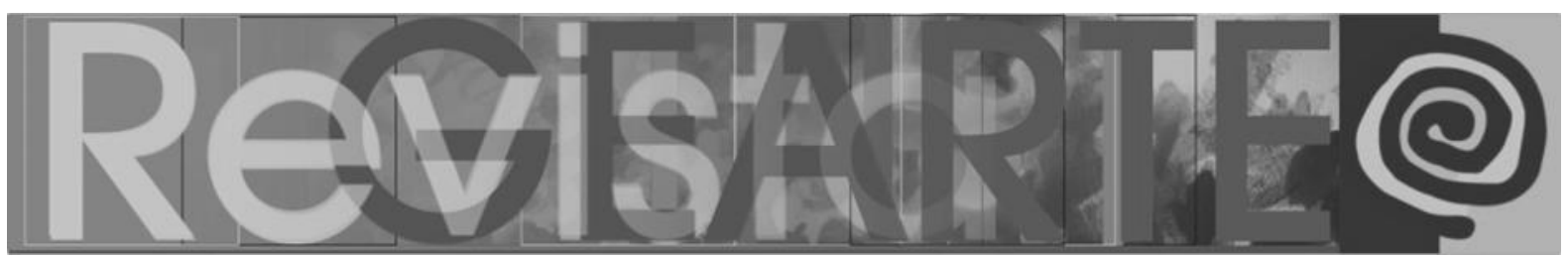

observação participante. Também, não foram delineados roteiros fixos, por entender que essas questões tomariam sentido e corpo com a própria imersão, com a abertura para as surpresas do caminho, dando vida ao que Santos propõe como sendo "[...] produzidas na medida em que a teoria (os materiais, as fontes, etc.) estudada se hibridiza com as práticas (o que se investiga, como, por quê, etc.) constituindo um amálgama que é inseparável" (SANTOS, 2005, p. 20) e inerente de uma viagem investigativa.

Quanto à análise, as interpretações foram elaboradas tomando as contribuições das formulações da Análise de Conteúdo (AC) com orientações em Bardin (2009), convergindo para o que dizem Nelson, Treichler e Grassberg sobre a receptividade dos estudos que adentram no campo dos Estudos Culturais às diferentes possibilidades de análises, dentre as quais, a Análise de Conteúdo, como possível para "[...] fornecer importantes insights e conhecimentos" (NELSON; TREICHLER; GRASSBERG, 2012, p. 9, grifo dos autores). Vale destacar que, dentre os conjuntos de técnicas possíveis, elegi a análise categorial por entender que essa técnica possibilitaria comprender melhor os diferentes registros realizados durante a inserção no campo.

A partir de Bardin (2009), a análise de conteúdo enquanto conjunto de técnicas, pode ser "[...] reinventada a cada momento" (BARDIN, 2012, p. 32), no caso da investigação realizada, esta reinvenção deu-se em função dos objetivos delineados e das aproximações teóricas com os(as) estudiosos(as) da etnografia numa perspectiva contemporânea. Isso implica afirmar que o processo de análise pode ser visto também caleidoscopicamente, uma vez que foram unidas diferentes peças para compor a narrativa etnográfica que estrutura a pesquisa.

Da etnografia contemporânea, destaco a estratégia da evocação no lugar da descrição e isso implica dizer que utilizei as recordações de elementos das memórias e registros "[...] em vez de tentar convencer o leitor da verdade dos relatos, apelando para formas textuais em que a autoridade acadêmica se torne 


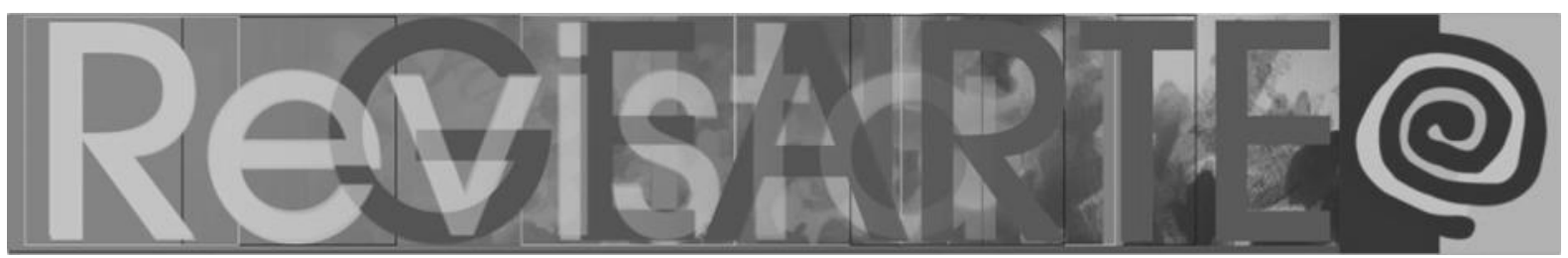

critério de fidedignidade do texto", pois nessa perspectiva com a qual me inspirei, os(as) etnógrafos(as) "[...] tentam promover uma compreensão mediante reconhecimento, identificação, experiências pessoais, emoção, discernimento e formas de comunicação que comprometam o/a leitor/a com planos outros que unicamente o racional" (KLEIN; DAMICO, 2012, p. 68). Sendo assim, a bagagem de pesquisadora etnógrafa foi sendo composta aos poucos, juntando peças, ao mesmo tempo em que me deparava com as leituras.

Por fim, destaco que, apoiada em Larrosa (2006), entendo os limites da pesquisa, da experiência e da própria narrativa etnográfica, uma vez que uma escrita não contempla todas as formas possíveis de ver, sentir, escrever, analisar e compreender o campo, os sujeitos e tudo o que mobilizou a pesquisa, são, também, cantos de experiências, recortes e rastros das reflexões e interpretações do que foi vivido, conforme esclarece o fragmento abaixo:

\begin{abstract}
Porque a experiência tem a ver também com o não saber, com o limite do que já sabemos, com o limite do nosso saber, com a finitude do que sabemos. E com o não poder dizer, com o limite do que já sabemos dizer, do que já podemos dizer, com o limite da nossa linguagem, com a finitude do que dizemos. E com o não poder pensar, com o limite do já sabemos pensar, do que já podemos pensar, com o limite de nossas ideias, com a finitude do nosso pensamento. E com o não poder, com o não não saber o que fazer, com nossa impotência, com o limite do que podemos, com a finitude de nossos poderes. (LARROSA, 2006, p. 111)
\end{abstract}

\title{
Rastros dos pontos de paradas, dos atravessamentos e interpretações dos registros realizados lá
}

Ao olhar para trás, para o percurso investigativo vivido, percebo que a viagem realizada na experiência da pesquisa permitiu entender um pouco mais do contexto, revelado pelos caminhos percorridos, pelas rotas traçadas e pelas escolhas feitas. Nesse sentido, o trecho da música Retrovisor, do grupo O Teatro Mágico, torna-se pertinente para ilustrar esse momento de (re)visitar o vivido: 


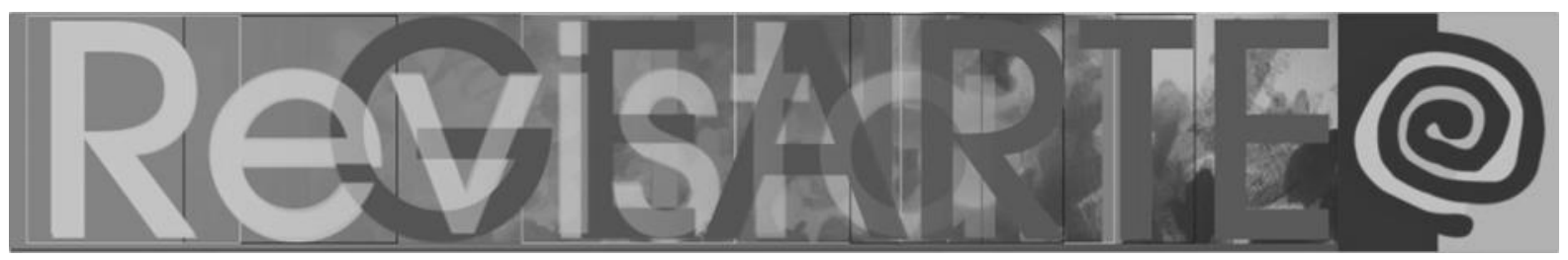

Retrovisor mostra meus olhos com lembranças mal resolvidas

Mostra as ruas que escolhi

Calçadas e avenidas

Deixa explícito que se for pra frente

Coisas ficarão pra trás

A gente só nunca sabe que coisas são essas. (ENTRADA para raros, 2008)

Em alguns momentos, a viagem pareceu mais desafiadora, pois o lugar visitado, o curso de Pedagogia da UFPE, não é um lugar estranho, é o lugar do meu convívio profissional cotidiano e de outras ações pesquisantes, onde passo grande parte do meu tempo imersa em distintas funções - ensino, pesquisa, extensão e gestão. Isso me exigiu uma postura diferente, ou seja, demandou exercitar outros modos de ver, perceber, (re)conhecer o que parece familiar.

Localizada na zona oeste do Recife, a Universidade Federal de Pernambuco é uma instituição de ensino superior público federal. Ela é responsável pela formação acadêmica em diferentes níveis e tem contribuído para vários campos de conhecimento, dentre os quais, destaco, o curso de Licenciatura em Pedagogia, pertencente ao Centro de Educação (CE), centro acadêmico responsável pela articulação na formação de professores(as) das demais licenciaturas, além da educação básica oferecida pelo Colégio de Aplicação.

Como se não conhecesse aquele lugar, de caderninho na mão, dei início à observação, escolhi passar boa parte da minha manhã parada, presenciando e olhando atentamente tudo o que se passava na frente do CE. Ao mesmo tempo, tentei jogar fora todas as impressões anteriores e me dei conta de que, na correria do meu cotidiano, não havia parado por tanto tempo naquele lugar e, também, de que a frente do $\mathrm{CE}$, em muitos momentos, foi somente o meu lugar de passagem.

Sentei em um dos bancos e parei para olhar a paisagem que cerca aquele lugar. Poucos metros à frente, percebi uma imensa área de terra utilizada como estacionamento para carros. Em dias de sol, poeira, em dias de chuva, lamas e buracos. Também do mesmo banco, foi possível ver uma árvore brigando pra sobreviver junto a uma mureta de cimento. Ao meu lado, havia uma barraca 


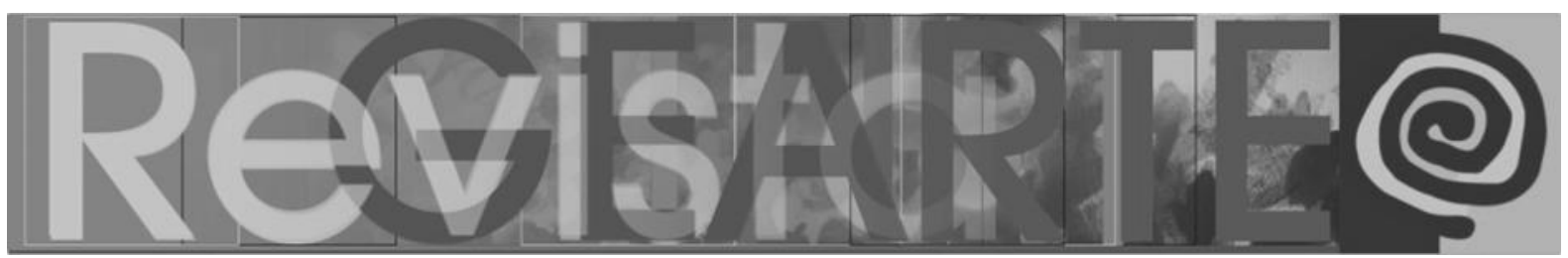

vendendo lanches, tapiocas feitas na hora e café quentinho, que espalhava o cheiro pelo ambiente. Na minha frente, encontrava-se um pequeno jardim, quase sempre muito bem cuidado, com a grama aparada e flores vermelhas. Dei alguns passos e fui até o meio do jardim, levantei o olhar para a fachada e percebi o enorme grafite (Figura 1) realizado no período em que iniciei a pesquisa por Heron de Barros Dória, mais conhecido como Azul de Barros, grafiteiro e arquiteto recifense, em parceria com Jakson Toff, grafiteiro, ilustrador e produtor da cidade do Recife.

\section{Figura 1 - Azul de Barros e Jakson Toff, 2012 - Grafite na fachada do Centro de Educação/UFPE}

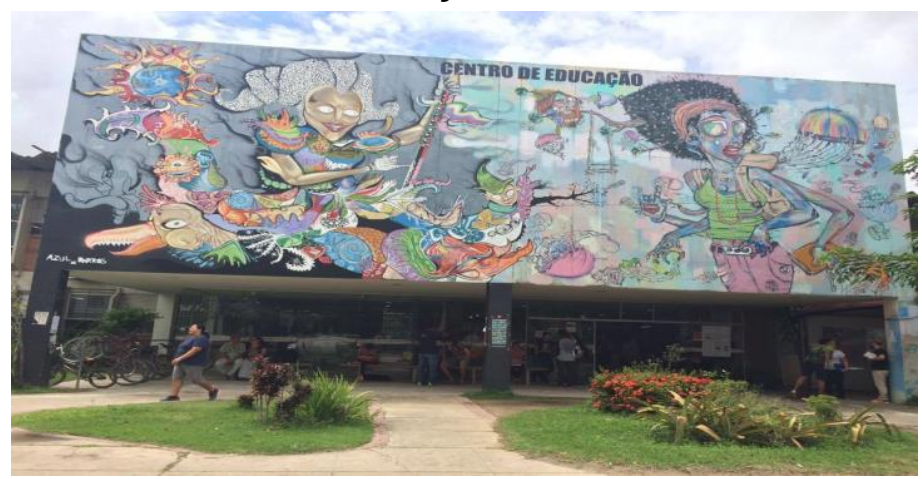

Fonte: Foto do arquivo de Fabiana Vidal (2012).

Por muito tempo, o grafite na fachada foi motivo de espanto, como nos relatou um estudante, aludindo ao fato de que nem o Centro de Artes e Comunicação (CAC), espaço que prioritariamente esperamos ver arte, tem uma fachada como a do CE: "Aqui é mais bonito que o Centro de Artes e Comunicação (CAC), esse grafite ficou muito diferente, nem parece o CE!" - disse o estudante. De certo modo, ao olhar para o grafite e pensar, ao mesmo tempo, no objeto que mobilizou a investigação, as formações estéticas/culturais de professores(as), ficou em suspenso a expectativa para o que encontraria ao adentrar. Então, uma pergunta passou a reverberar: se a fachada tem algo tão contemporâneo, como a linguagem do grafite, o que será que reserva o interior?

Destaco que o grafite não foi realizado e aceito de forma harmoniosa por todos(as) que integram o Centro de Educação, ao contrário, ele provocou grandes tensionamentos, juntamente com as demais ações promovidas pela direção do CE 


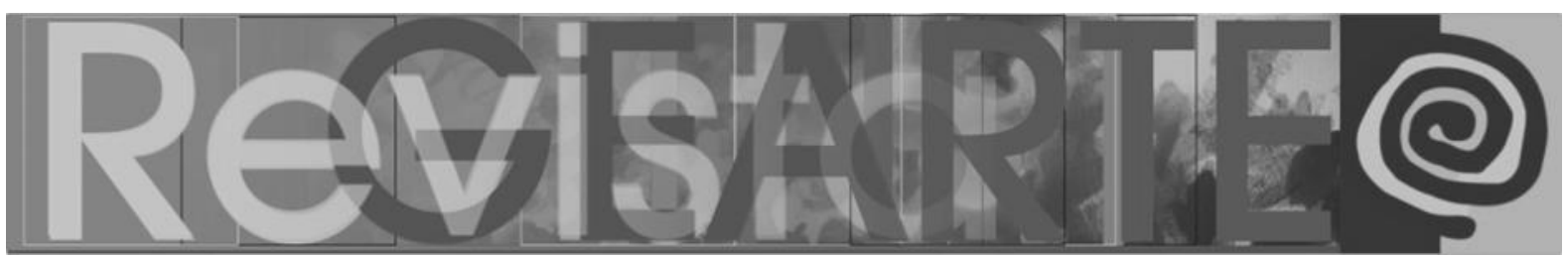

na época, quando, ao mesmo tempo, várias intervenções também foram realizadas no hall e em alguns corredores, trazendo um acalorado debate sobre grafite e pichação. Na ocasião, fui interpelada por uma professora que, demonstrando sentir-se um tanto indignada com tudo o que via naquele momento e com um certo tom de desconsideração pela produção artística do grafite na fachada - como se este tipo de produção não fosse bem-vinda em um Centro de Educação perguntou: "Você que é da Arte, me diga, aquilo é Arte?".

Passado algum tempo, o grafite, que ainda hoje continua na fachada do $\mathrm{CE}$, com suas cores vibrantes, suas formas e figuras que remetem a um sonho ou a uma imagem surrealista, continuou instigando o imaginário de quem passava, mexendo com alguns(mas) estudantes e sendo pauta de discussões. A exemplo disso, existem os registros realizados em dois debates em uma das componentes curriculares observadas, demonstrando ainda provocar reações diversas e sendo disparador de reflexões:

Estudante: Essa imagem foi um escândalo aqui no Centro".

Docente: É, porque mexe com nossas representações do que é Arte, do que não é, do que é uma prática cultural aceitável e o que não é (Registro do Diário de Campo 4).

Ao trabalhar as relações com imagens que cercam nosso cotidiano, o grafite da entrada do CE passa a ser discutido, gerando falas diversas. Nesse momento, a docente interpela:

\begin{abstract}
A gente já deveria trabalhar aqui essa própria diferenciação entre pichação e grafite. Qual a relação disto com as nossas práticas culturais? E a gente podia fazer relação com outras expressões que nos fazem referência a isso, não é? Os muralistas mexicanos. A questão é a gente trabalhar a temporalidade. Transitando em vários espaços (Registro do Diário de Campo 4).
\end{abstract}

Dando continuidade, passo a apresentar algumas experiências de formações estéticas/culturais vivenciadas em três das componentes curriculares, como dito anteriormente, e que compuseram as observações participantes. Em tempo, faz-se necessário destacar, pelos debates travados em algumas aulas, que 


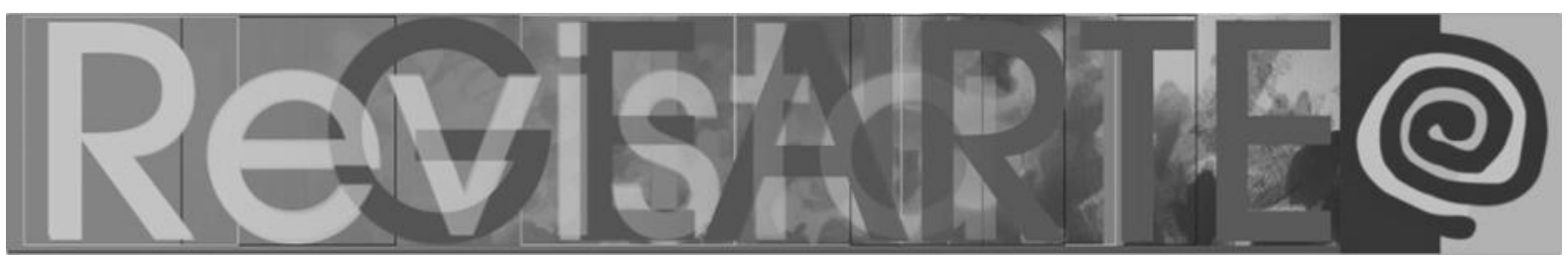

havia uma concepção de arte por parte dos(as) estudantes que vivenciavam as três componentes curriculares, geralmente, ligada a uma ideia de arte como algo a ser experienciado, vivido e praticado por poucas pessoas, além de falas e olhares suspeitos para produções artísticas contemporâneas e para tudo o que se distanciava do que tradicionalmente é tido como arte. Essas concepções ressaltam o fato de sermos herdeiros(as) de uma tradição elitista que dita o que pode e deve ser considerado arte e quem pode e deve ser leitor(a) de produções artísticas, o que contribui significativamente para silenciar àqueles(as) que foram culturalmente convencidos(as) a pensar dentro desses moldes. Como nos lembra Darras (2006):

A educação das artes, que nós chamaríamos hoje de 'educação artística', faz parte há muito tempo da formação e das práticas de uma parte privilegiada da população (letrada e aristocrática). A educação artística, tal qual nós a conhecemos hoje, é não somente herdeira destas práticas, mas também depositária do sistema de valores e de organização social defendidos por estes privilegiados. (DARRAS, 2006, p. 4)

Essas normas elitistas tratadas pelo autor não apenas ditam modos de pensar, como também silenciam e distanciam parte dos sujeitos das práticas culturais, que acabam sendo culturalmente FORMAdos(as) a pensar arte como algo que não Ihes pertence. Sobre isso, o fragmento de observação abaixo nos faz pensar um pouco mais:

Docente: 'Qual o sentimento que toca, que faz você acreditar no cinema? Como o cinema pega você?'. Nesse momento, o depoimento de uma estudante deixou todos(as) pensativas(os), quando disse: "Eu mesma vim pra essa disciplina porque não tenho nenhuma relação com o cinema, nunca fui no cinema e acho que deve ser até cansativo assistir um filme inteiro, nem em casa eu assisto. Nunca fui estimulada a ver filmes" (Registro do Diário de Campo 3).

Certamente, a lacuna de experiências com filmes relatada pela estudante não foi desfeita, mas, ao longo do semestre, a possibilidade de assistir 8 filmes Viagem à lua, 1902, direção de Georges Méliès; Cinema Paradiso, 1988, direção de Giuseppe Tornatori; Recife Frio, 2009, direção de Kleber Mendonça Filho; Janela da Alma, 2001, direção: João Jardim e Walter Carvalho; Matrix, 1999, direção de Lana Wachowski e Lilly Wachowski; A Onda, 2008, direção de Dennis 


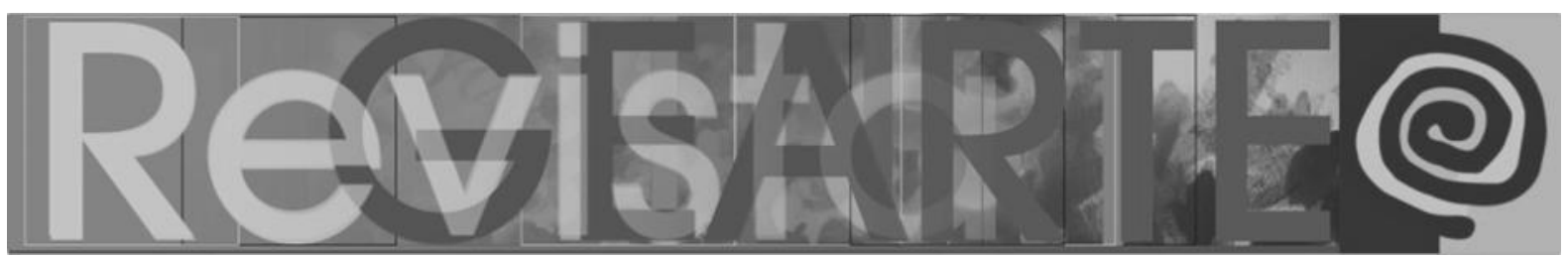

Gansel; O Substituto, 2013, direção de Tony Kaye; Escritores da Liberdade, 2007, direção de Richard LaGravenese - e dialogar com estas produções, pensar as relações que os filmes estabelecem com cada sujeito, com a escola e com a vida, provocou alguns rebatimentos e deixou pistas e aberturas para outras experiências.

O aspecto ressaltado me leva a inferir que o curso de Pedagogia, ao inserir uma componente curricular voltada para a discussão sobre cinema, assume uma abertura e aponta para uma concepção de currículo contemporânea, discutida por Costa (2005), com a inserção e a articulação de saberes que comunicam as coisas do mundo. Ao analisar o fragmento sob a ótica dos Estudos Culturais, me deparo com Fischer quando afirma que: "[...] há que se propor algo à sociedade, sobretudo àqueles que, por razões de posições outras de sujeitos, na escala social e econômica, não teriam acesso a certos conhecimentos e práticas senão pela mediação de alguns agentes, como os professores, estudiosos e pesquisadores" (FISCHER, 2010, p. 16).

A reflexão acima contribui como uma lupa para compreender, também, a fala de uma estudante em uma aula de campo organizada pela componente curricular do campo da arte para a visita a três equipamentos culturais - Paço do Frevo (Imagem 2), Museu Cais do Sertão (Imagem 3) e Centro Cultural dos Correios. Eles são localizados no bairro do Recife Antigo, conhecido por abrigar grande parte dos equipamentos culturais da cidade do Recife e por oferecer recorrentemente ações culturais diversas. 


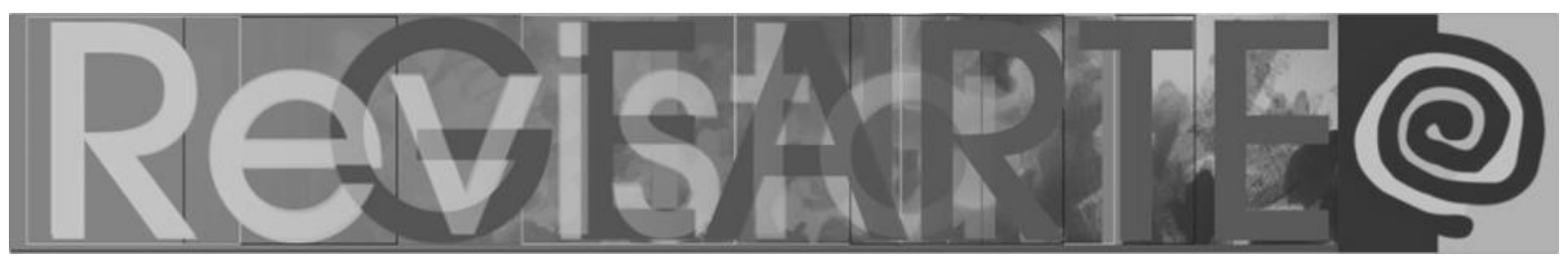

Figura 2 - Paço do Frevo, Recife

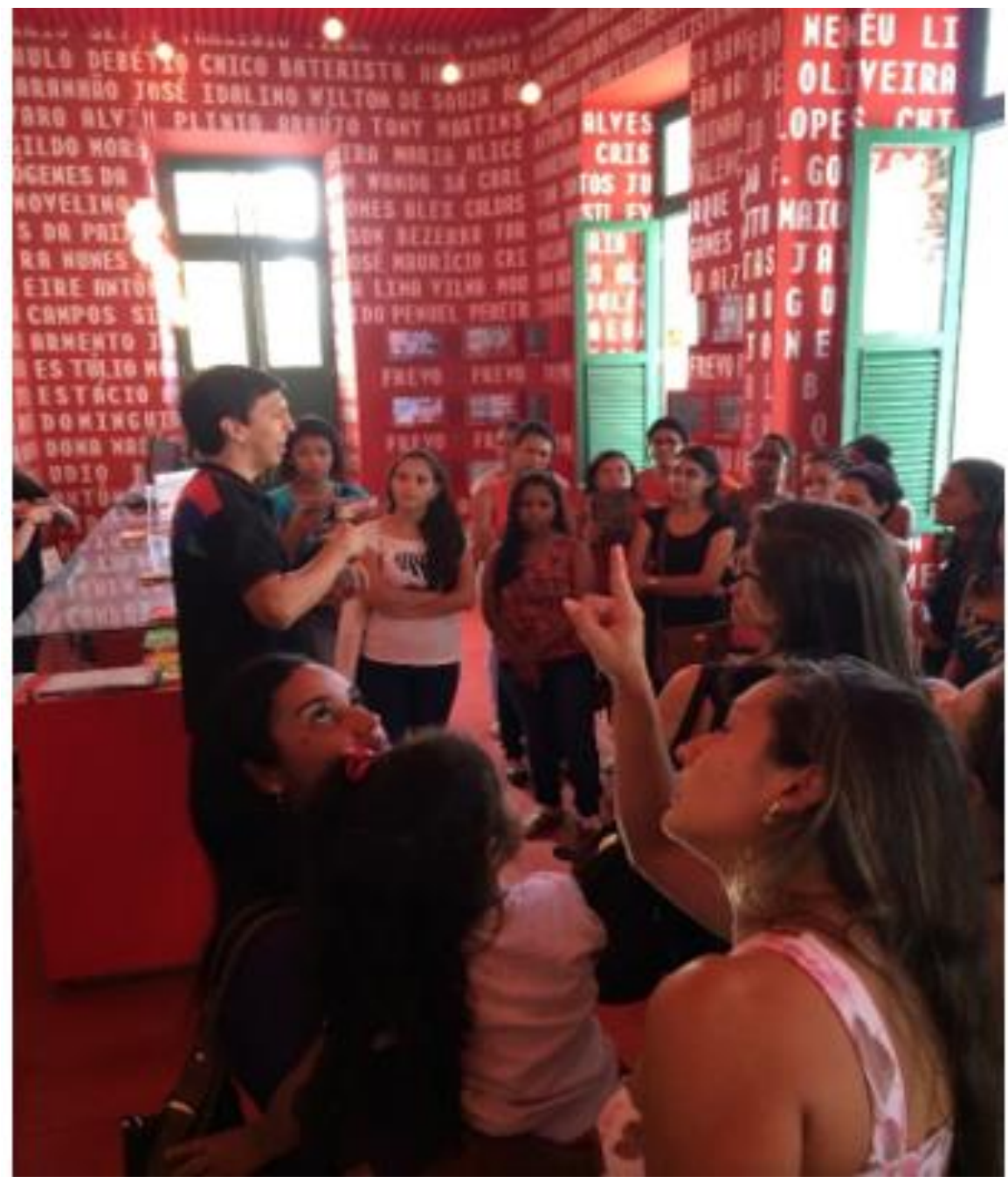

Fonte: Foto do arquivo de Fabiana Vidal (2014). pistas, recortes e rastros de um percurso investigativo no curso de Pedagogia da UFPE. Revista GEARTE, Porto Alegre, v. 8, n. 2, p. 322-346, maio/ago. 2021.

Disponível em: http://seer.ufrgs.br/gearte 


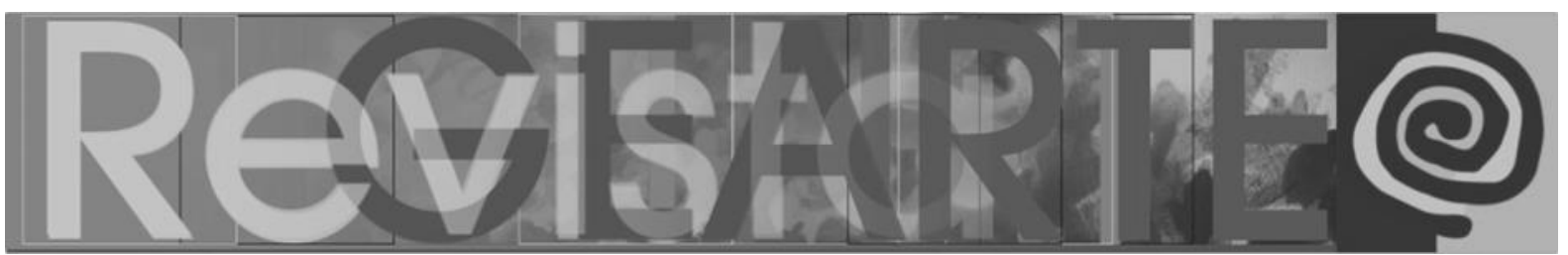

Figura 3 - Museu Cais do Sertão, Recife

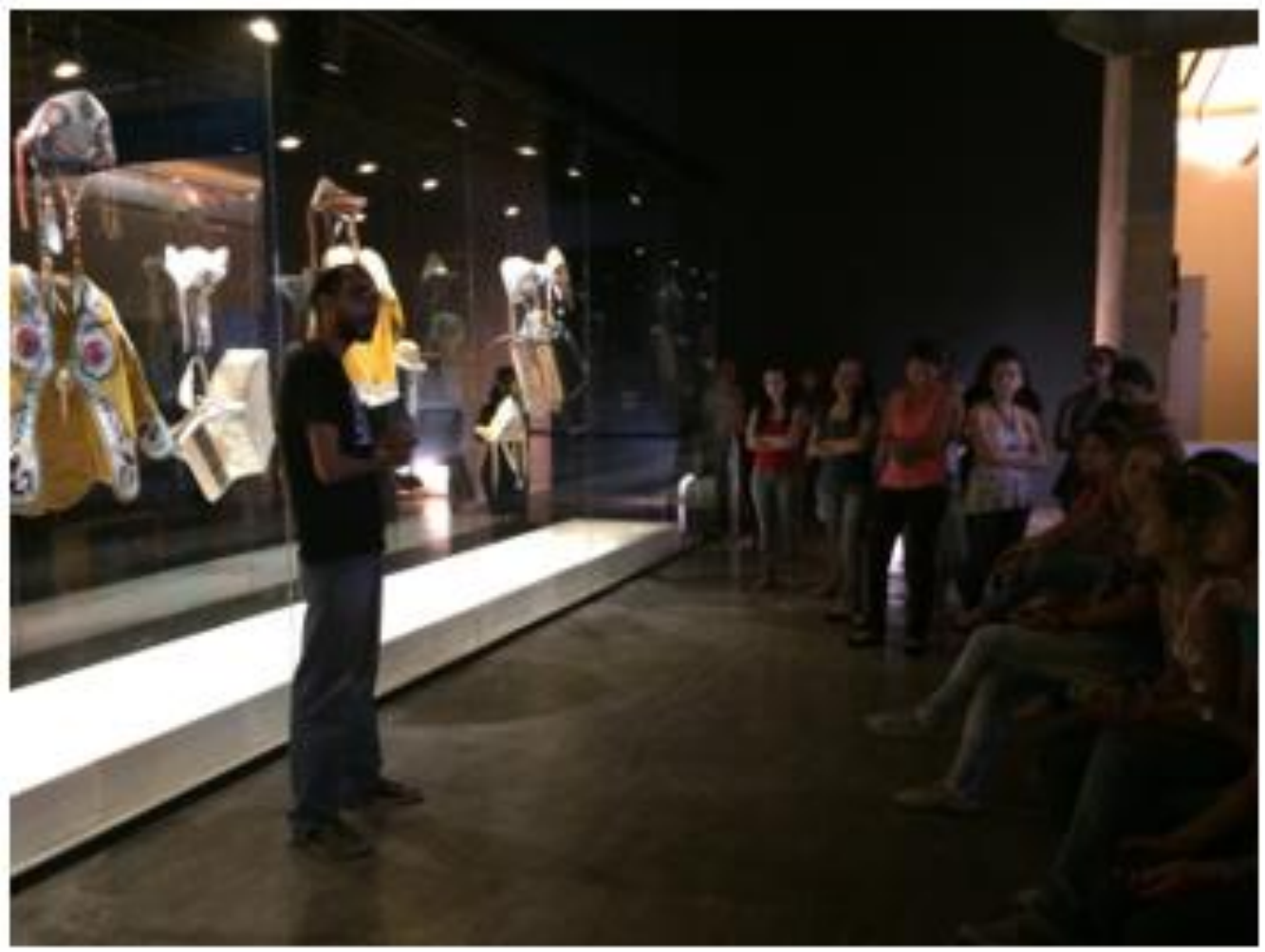

Fonte: Foto do arquivo de Fabiana Vidal (2014).

Durante o deslocamento, uma estudante relatou seu espanto com a arquitetura e destacou que nunca tinha visitado aquele bairro, mesmo sendo moradora da cidade do Recife; também, ela disse que estava achando tudo muito lindo e interessante. Ao pensar sobre esse momento, mais uma vez sou levada a refletir sobre o compromisso de todos(as) que atuam na formação de professores(as), isto é, em proporcionar momentos formativos, estéticos e culturais que derrubam as paredes das salas de aula, extrapolam suas fronteiras e/ou trazem para a formação diferentes práticas e experiências estéticas/culturais. Para pensar sobre isso, recorro novamente a Fischer quando sugere que isso implica em adotar, para a formação de professores(as), políticas comprometidas com teorias que se constroem e se criam para "[...] fazer diferença no mundo em que vivemos, que produzam efeitos concretos sobre os sujeitos, mesmo que isso não venha a ocorrer de imediato" (FISCHER, 2010, p. 16). 


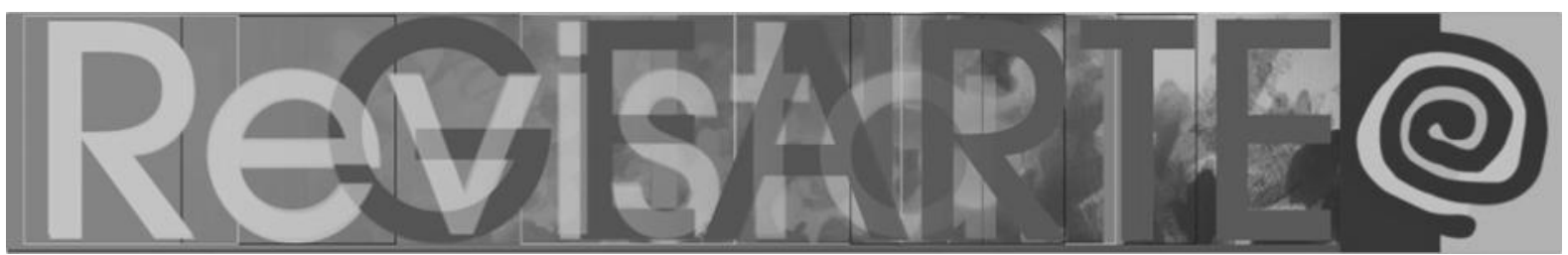

Para refletir um pouco mais sobre rastros de formação estética/cultural, seguem dois fragmentos dos registros realizados em duas componentes curriculares:

A aula inicia com a sala está cheia, a docente distribui diversos catálogos de artistas visuais: Frida Kahlo, Nelson Leirner, Mestre Vitalino, Vick Muniz, José Patrício. Todos os catálogos circularam pelos(as) estudantes para que pudessem folhear e conhecer. Enquanto folheavam, a professora apresentou um pouco de cada artista, as características, o contexto da produção. Os(as) estudantes se mostraram curiosos(as), folheavam e discutiam as imagens entre si, opinavam sobre como podiam usá-las em sala de aula, tornando este momento significativo e em conexão com o que estava sendo estudado (Registro do Diário de Campo 2).

Na pauta da aula, a docente explica que irá iniciar as atividades do dia com o vídeo 'Recife de dentro pra fora', de Kátia Mesel, curta-metragem inspirado no poema 'O cão sem plumas' de João Cabral de Melo Neto, com músicas na voz de Zé Ramalho, Elba Ramalho e Geraldo Azevedo. Nesse momento, uma estudante interrompe para perguntar quem foi João Cabral de Melo Neto e prontamente a docente responde que foi um poeta pernambucano, autor de 'Morte e Vida Severina' (Registro do Diário de Campo 4).

Vejamos trechos do poema que inspirou o vídeo trabalhado na aula e, também, o frame do curta exibido:

Figura 4 - Trechos do Poema "O cão sem plumas", de João Cabral de Melo Neto

I - (Paisagem do Capibaribe) II - (Paisagem do Capibaribe)

A cidade é passada pelo rio como uma rua é passada por um cachorro; uma fruta por uma espada.

Entre a paisagem

o rio fluía como uma espada de líquido espesso. como um cão humilde e espesso.

O Rio ora lembrava a língua mansa de um cão, ora o ventre triste de um cão, ora o outro rio de aquoso pano sujo dos olhos de um cão.

Entre a paisagem

(fluía)

de homens plantados na lama; de casas de lama plantadas em ilhas coaguladas na lama; paisagem de anfibios $\lceil\ldots\rceil$ de lama e lama.

Fonte: Revista Continente Multicultural (2020, p. 60 e 64). 


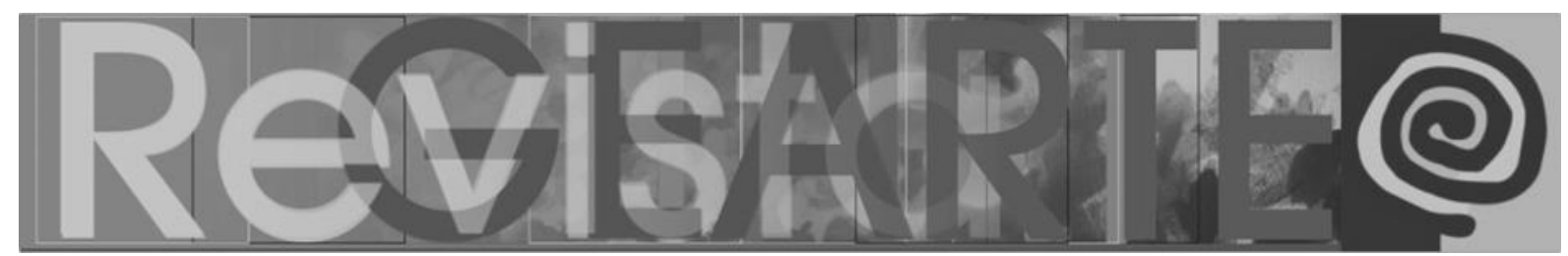

Figura 5 - Fragmentos do filme "Recife de dentro pra fora”, 7’58”, 1997 Direção: Kátia Mesel

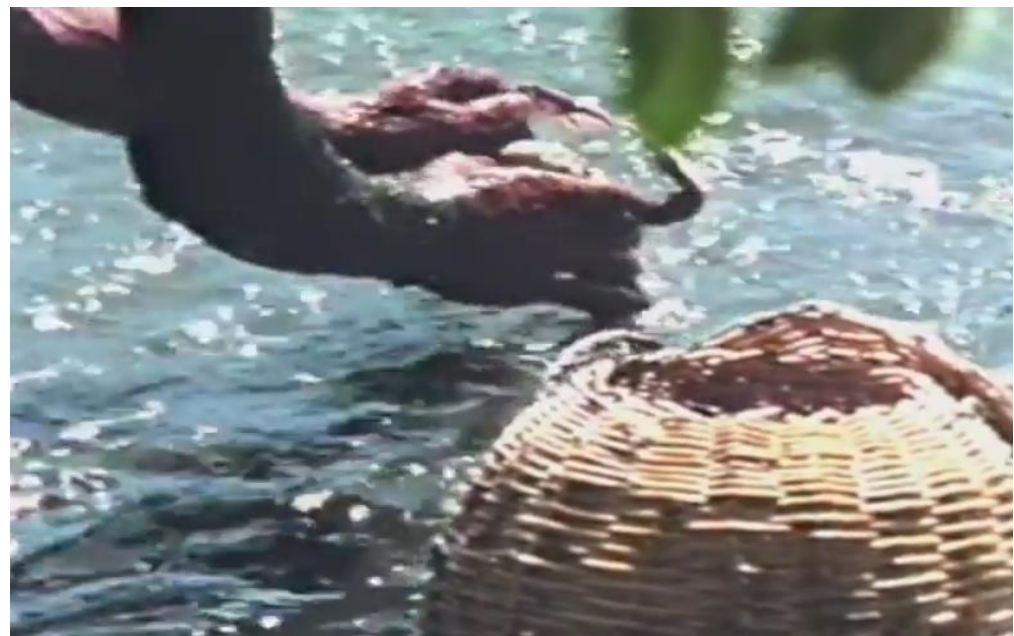

Fonte: Fragmentos do filme Recife de dentro pra fora, 1997. Direção: Kátia Mesel. Recorte das imagens: Fabiana Vidal. Disponível em: <https://www.youtube.com/watch?v=asULkiyJzrQ>. Acesso em: 09 abr. 2014.

Após a exibição do filme, com uma duração média de 15 minutos, a docente pergunta se alguém já conhecia o vídeo. Nenhum(a) estudante se pronuncia afirmativamente. Nesse momento, percebemos que, na perspectiva adotada pela componente curricular, o filme foi utilizado como forma de trabalhar as referências teóricas da disciplina. A docente aproveita a discussão e defende a importância para a perspectiva adotada disciplina de buscar se relacionar com outros campos, trabalhar com diferentes fontes, desse modo, ressalta as conexões com imagens, com a literatura, com as pequenas histórias que constroem histórias (Registro do Diário de Campo 4).

Os fragmentos apresentados revelam que as vivências relatadas transformaram os momentos de aulas e a apresentação de conteúdos em formações estéticas/culturais provocadas pelas experiências estéticas de leituras críticas, também apontaram pistas, caminhos e promoveram reflexões. Sobretudo, reflexões com rebatimentos para pensar as práticas e o contexto educacional com o qual os(as) futuros intérpretes e trabalhadores(as) culturais poderão atuar, para pensar o próprio campo das componentes curriculares da formação, para pensar suas próprias identidades, sem perder de vista a importância de considerar também as referências estéticas/culturais que circularam nas aulas e que estão presentes no cotidiano dos sujeitos com os(as) quais trilharão outros caminhos formativos. 


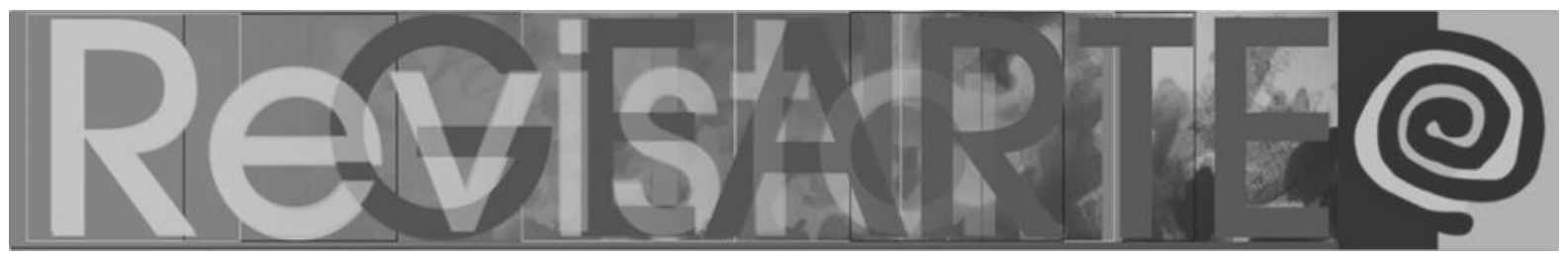

\title{
Algumas marcas deixadas pelas trilhas visitadas
}

Ao tentar um equilíbrio entre as tensões do campo e a imersão nele, mas, ao mesmo tempo, encantada pela instabilidade e pelas belezas que esse lugar tão específico - a pesquisa - revelou acerca das experiências de formações estéticas/culturais de professores(as) no curso de Pedagogia, passei a pensar que 0 ato de pesquisar e de comunicar uma pesquisa é também a busca pelos encantamentos proporcionados pelo movimento próprio do processo de investigação, nesse sentido, estabeleço uma relação com o poema de Roseana Murray (1998):

\author{
Procura-se um equilibrista \\ que saiba caminhar na linha \\ que divide a noite do dia \\ que saiba carregar nas mãos \\ um fino pote cheio de fantasia \\ que saiba escalar nuvens arredias \\ que saiba construir ilhas de poesia \\ na vida simples de todo o dia. (MURAY, 1998, p. 9)
}

Com Larrosa (2014), Dewey (2010b) e Duve (2009) posso inferir que os fragmentos relatados neste artigo e vivenciados em diferentes componentes curriculares aproximam-se da ideia de experiência como algo que nos passa, nos atravessa e nos toca. Ao mesmo tempo, também se aproxima de uma experiência consumatória de leitura estética e contribui significativamente para ampliar a dimensão estética na/para a formação de professores(as), apoiada na ideia de que o estímulo à experiência de ver, vivenciar e conhecer diferentes produções artísticas, de fazer comparações e de analisar para ampliar o acervo pessoal, são elementos essenciais para formar o gosto e as preferências e para transformar os modos de ver/ser/estar/agir no mundo, a partir dos atravessamentos vividos.

Ao expandir o repertório estético/cultural dos(as) estudantes, a formação de professores(as) provoca, ao mesmo tempo, um movimento de comparação, confronto com outras experiências vivenciadas e de expansão do repertório estético/cultural de cada estudante. Além disso, as vivências relatadas em componentes curriculares, não apenas do campo da arte, deixam pistas para 


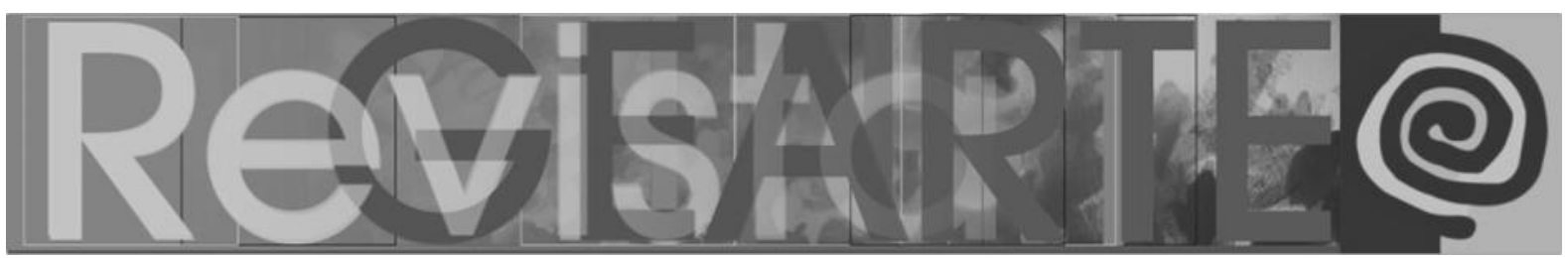

entender que experiências estético/culturais significativas em toda a formação inicial abrem espaços para agregar elementos na formação dos sujeitos, ampliam as possibilidades de leituras nos mais diferentes campos, o que poderá rebater nos modos de tecer redes de conhecimentos em suas práticas futuras. Elas são, portanto, elementos fundantes e urgentes na/para a formação de professores(as).

Para encerrar as reflexões provocadas, encontro em Barbosa quando acrescenta que "[...] a educação se torna mais reflexiva à medida que os alunos se tornam conscientes de seu papel como intérpretes culturais" (BARBOSA, 2003, p. 11). Desse modo, a autora deixa pistas para pensar os recortes de experiências destacados no presente texto, o que vai ao encontro do duplo compromisso da formação de professores(as), no que se refere a alimentar os(as) estudantes de uma formação estético/cultural, contribuindo para que se percebam enquanto intérpretes culturais e, ao mesmo tempo, para abastecê-los(as) de elementos que Ihes permitam ser protagonistas.

\section{Notas}

1 Parte deste artigo é fruto da tese intitulada Um olhar caleidoscópico nas/para as formações estéticas/culturais de professores(as): experiências e construções de identidades docentes estéticas no curso de Pedagogia da UFPE defendida pelo Programa de Pós-Graduação em Educação da UFPE, em 2016, sob orientação da Professora Doutora Clarissa Martins de Araújo e disponível na íntegra na BDTD. (VIDAL, 2016).

2 No presente artigo, as referências e citações em língua estrangeira são traduções livres.

3 Das três componentes curriculares, duas são disciplinas obrigatórias - Fundamentos do Ensino de Artes, ministrada, à época, por uma docente substituta, e Fundamentos do Ensino da História, ministrada por uma docente efetiva - e uma disciplina eletiva, Cinema e Educação, ministrada por duas docentes efetivas.

\section{Referências}

A ONDA. Direção de Dennis Gansel. Alemanha: Constantin Film, 2008. (107min).

BARBOSA, Ana Mae. Carta Prefácio. In: RICHTER, Ivone Mendes. Interculturalidade e estética do cotidiano no ensino das artes visuais. Campinas: Mercado das Letras, 2003.

BARDIN, Laurence. Análise de Conteúdo. 4. ed. Portugal: Edições 70, 2009.

CANAL FUTURA: Caderno Maleta Toda Beleza. BARBOSA, Ana Mae. Cultura, Arte, Beleza e Educação. Texto de assessoria do Programa Toda Beleza. p. 5-25, 2008. Disponível em: <http://www.maletafutura.org.br/docs/caderno_maleta_toda_beleza.pdf>. Acesso em jun. 2021. 


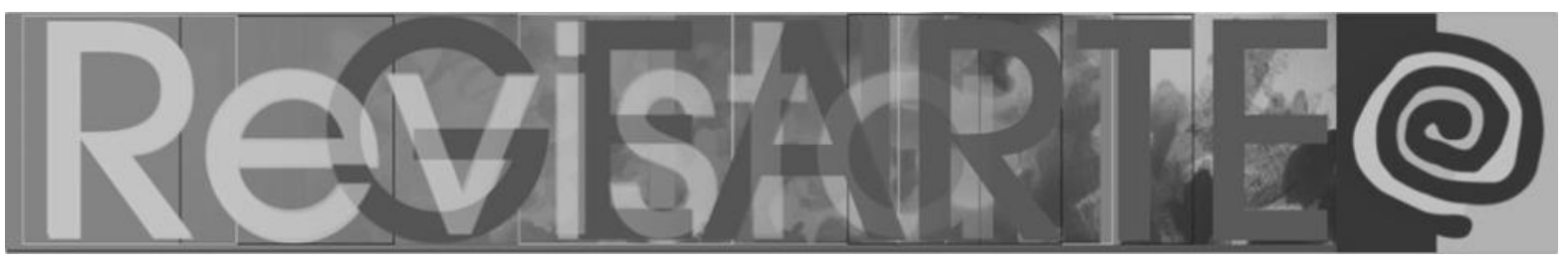

CINEMA Paradiso. Direção de Giuseppe Tornatore. Itália: Titanus, 1988. (155min).

COSTA, Marisa Vorraber; BUJES, Maria Isabel Edelweiss. (org.). Caminhos Investigativos III: riscos e possibilidades de pesquisar nas fronteiras. Rio de Janeiro: DP\&A, 2005.

COSTA, Marisa Vorraber; SILVEIRA, Rosa Hessel; SOMMER, Luis Henrique. Estudos Culturais, educação e pedagogia. Revista Brasileira de Educação, Rio de Janeiro, n. 23, p. 36-61, ago. 2003.

DARRAS, Bernard. Géométrie de la culture. Revue Media et Information (MEI), Paris, n. 3, 1995.

DARRAS, Bernard. De l'éducation artistique à l'éducation culturelle. In: CONFERENCE MONDIALE SUR L'ÉDUCATION ARTISTIQUE. 21., 2006. Anais [...]. Lisbonne: UNESCO; Gouvernement du Portugal, 2006.

DEWEY, John. Experiência e Educação. Petrópolis, RJ: Vozes, 2010a.

DEWEY, John. Arte como experiência. São Paulo: Martins Fontes, 2010b.

DUVE, Thierry de. La nouvelle donne - Remarques sur quelques qualifications du mot "art". In: GENIN, Christophe; LEROUX, Claire; LONTRADE, Agnès (org.). Juger l'art? Collection Esthétique. 16. Paris: Publications de la Sorbonne, 2009.

ENTRADA para raros. Produção: Daniel Pereira. São Paulo: Gravadora Independente, 2008. 1 DVD (93 min). ESCRITORES da Liberdade. Direção de Richard LaGravenese. Estados Unidos: Paramount Pictures, 2007. (122min).

FINO, Carlos Nogueira. A etnografia enquanto método: um modo de entender as culturas (escolares) locais. In: ESCALLIER, Christine e VERÍSSIMO, Nelson (org.). Educação e Cultura. Funchal: DCE - Universidade da Madeira, 2008.

FISCHER, Rosa Maria Bueno. Cultura e educação, tensão nas fronteiras. In: BUJES, Maria Isabel Edelweiss, BONIN, lara Tatitana. Pedagogias sem fronteiras. Canoas: Editora ULBRA, 2010.

GEERTZ, Clifford. A interpretação das culturas. 1. ed. Rio de Janeiro: Editora LTC, 2012.

GENIN, Christophe (org.). Images et esthétique. Collection Esthétique. Paris: Publications de la Sorbonne, 2007.

GIROUX, Henry. Cruzando as fronteiras do discurso educacional: novas políticas em educação. Porto Alegre: Artes Médicas, 1999.

JANELA da Alma. Direção de João Jardim e Walter Carvalho. Rio de Janeiro: Copacabana Filmes e Produções, 2001. (64min).

KERLAN, Alain. L'art pour éduquer? La tentation esthétique - Contribution philosophique à l'étude d'un paradigme. Québec: Les Presses de l'Université Laval, 2004.

KLEIN, Carin, DAMICO, José. O uso da etnografia pós-moderna para a investigação de políticas públicas de inclusão social. In: MEYER, Dagmar Estermann; PARAíSO, Marlucy Alves. (org.). Metodologias Pós-Críticas em Educação. Belo Horizonte: Mazza Edições, 2012.

LAUAND, Jean. Prefácio. In: PERISSÉ, Gabriel. Estética e Educação. Belo Horizonte: Autêntica Editora, 2009.

LARROSA, Jorge. Sobre la experiencia. Aloma: Revista de psicologia, ciències de l'educación i de l'esport Blanquerna [en línia], 2006, n. 19, p. 87-112. Disponível em: http://www.raco.cat/index.php/ Aloma/article/view/103367/154553. Acesso em: 21 set. 2014.

LARROSA, Jorge. Tremores: escritos sobre experiência. Belo Horizonte: Autêntica Editora, 2014.

LARROSA, Jorge; KOHAN, Walter. Apresentação. In: LARROSA, Jorge. Tremores: escritos sobre experiência. Belo Horizonte: Autêntica Editora, 2014. 


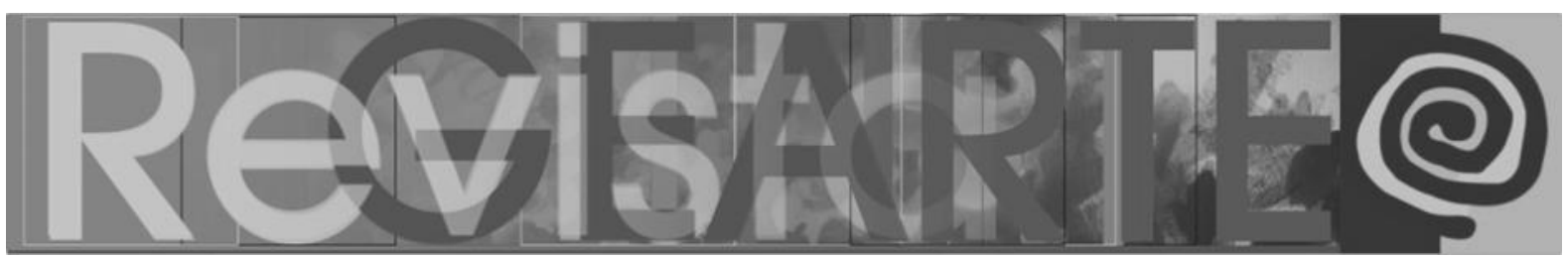

MATRIX. Direção de Lana Wachowski e Lilly Wachowski. Produção de Joel Silver. Califórnia: Warner Bros., 1999.

MEYER, Dagmar Estermann; PARAíSO, Marlucy Alves. Metodologias de pesquisas pós-críticas ou Sobre como fazemos nossas investigações. In: MEYER, Dagmar Estermann; PARAíSO, Marlucy Alves (org.). Metodologias Pós-Críticas em Educação. Belo Horizonte: Mazza Edições, 2012.

MURRAY, Roseana. Classificados Poéticos. 17. ed. Belo Horizonte: Miguilim, 1998.

NELSON, Cary; TREICHLER, Paula Al; GROSSBERG, Lawrence. Estudos Culturais: uma introdução. In: Alienígenas na sala de aula: uma introdução aos estudos culturais em educação". 4. ed. Rio de Janeiro: Vozes, 2012.

NETO, João Cabral de Melo. O cão sem plumas. In: Revista Continente Multicultural, ed. 229, Recife, 2020. Disponível em: https://revistacontinente.com.br/edicoes/229/o-cao-sem-plumas-. Acesso em: 15 abr. 2020.

O SUBSTITUTO. Direção de Tony Kaye. Estados Unidos: Orion Pictures, 2011. (100min).

PERISSÉ, Gabriel. Estética e Educação. Belo Horizonte: Autêntica Editora, 2009.

PRIBERAM, "flanar", in Dicionário Priberam da Língua Portuguesa [em linha]. Disponível em: https://dicionario.priberam.org/flanar. Acesso em: 11 ago. 2014.

RECIFE frio. Direção de Kléber Mendonça Filho. Cinemascópio/Símio Filmes. Produtores Associados: Cabraquente produções. Recife: Vitrine Filmes, 2009. (24 min).

RECIFE de Dentro Pra Fora. Direção e produção de Katia Mesel. Recife: Cinemateca Pernambucana, 1997. (16min). Disponível em: <http://cinematecapernambucana.com. br/filme/?id=3108> Acesso em jun. 2021.

SANTOS, Luís Henrique Sacchi dos. Sobre o etnógrafo-turista e seus modos de ver. In: COSTA, Marisa Vorraber; BUJES, Maria Isabel Edelweiss. (org.). Caminhos Investigativos III: riscos e possibilidades de pesquisar nas fronteiras. Rio de Janeiro: DP\&A, 2005.

SARAMAGO, José. Viagem a Portugal. 2. ed. São Paulo: Companhia das Letras, 2007.

SOURIAU, Etienne. Vocabulaire d'esthétique. Paris: Presses Universitaires de France, 1990.

VIAGEM à Lua. Direção e produção de Georges Méliès. França: Star Film, 1902. (14min).

VIDAL, Fabiana Souto. Um olhar caleidoscópico nas/para as formações estéticas/culturais de professores(as): experiências e construções de identidades docentes estéticas no curso de Pedagogia da UFPE. 2016. 370 p. Tese (Doutorado em Educação) - Centro de Educação, Universidade Federal de Pernambuco, Recife, 2016.

\section{Fabiana Souto Lima Vidal}

Professora de Artes Visuais do Colégio de Aplicação e da Universidade Federal de Pernambuco e do Programa Associado de Pós-Graduação em Artes Visuais UFPE/UFPB. Licenciada em Educação Artística/Artes Plásticas e Mestre em Educação na Universidade Federal de Pernambuco. Líder do Grupo de Pesquisa em Estudos Culturais e Arte/Educação (GPECAE).

ORCID: https://orcid.org/0000-0003-0439-7378

E-mail: fabiana.vidal@uol.com.br

Currículo: http://lattes.cnpq.br/9258272116465693

Recebido em 23 de fevereiro de 2021 Aceito em 30 abril de 2021 